\title{
Historical perspectives of The American Association for Thoracic Surgery: Paul C. Samson (1905-1982)
}

\author{
James I. Fann, MD, and John E. Connolly, MD
}

Paul C. Samson (Figure 1), the 48th president of The American Association for Thoracic Surgery (AATS), was born in Emporia, Kansas, in 1905. ${ }^{1,2}$ Growing up in the Midwest, he attended the University of Michigan, from which he graduated with a Bachelor of Science in Medicine and a Doctorate of Medicine cum laude in 1928. ${ }^{1}$ At 6 feet 6 inches tall, Samson acquired the nickname "Buck," not only for his formidable stature but also for his physical prowess and competitiveness. ${ }^{1,3}$ At the University of Michigan, he was an All-American swimmer, National Collegiate Athletic Association champion freestyler, and a member of 2 national championship water polo teams. A recipient of the Big Ten Conference Medal of Honor in 1927 for excellence in scholarship and athletics, Samson extended his aquatic prowess to the international level as a member of the United States Olympic Team in 1928 in Amsterdam. He swam the first leg of the 800 meter relay in the qualifying heat; however, he did not swim in the final, which was won by the United States team.

After graduation from medical school, Samson completed general surgical residency at Northwestern University, receiving his Master of Science in Surgery in 1935. He continued his surgical training at the University of Michigan as one of the trainees in the first thoracic residency program, directed by John Alexander, 17th AATS president. At Ann Arbor, he also worked with Lyman Brewer, 54th AATS president, a close friend and colleague with whom he would later extensively collaborate. ${ }^{1-3}$

The Alexander tradition and heritage of thoracic surgery was carried to the West when Samson began surgical practice in Oakland, California, in 1937. He joined the staff of several hospitals and sanitariums for tuberculosis in northern California and served in the Army Reserve Medical Corps from 1931 to 1941 . With involvement of the United States in World War II in December 1941, Samson joined the Second Auxillary Surgical Group and was deployed in the Mediterranean and European theaters. Along with treating traumatic injuries, he gained the distinction of

\footnotetext{
From the Department of Cardiothoracic Surgery, Stanford University, Stanford, Calif; and the Division of Cardiothoracic Surgery, University of California, Irvine, Calif.

Received for publication April 28, 2011; accepted for publication May 17, 2011; available ahead of print Aug 8, 2011

Address for reprints: James I. Fann, MD, Department of Cardiothoracic Surgery, Stanford University, 300 Pasteur Dr, Stanford, CA 94305 (E-mail: jfann@ stanford.edu).

J Thorac Cardiovasc Surg 2011;142:967-9

0022-5223/\$0.00

Published by Elsevier Inc. behalf of The American Association for Thoracic Surgery doi:10.1016/j.jtcvs.2011.05.014
}

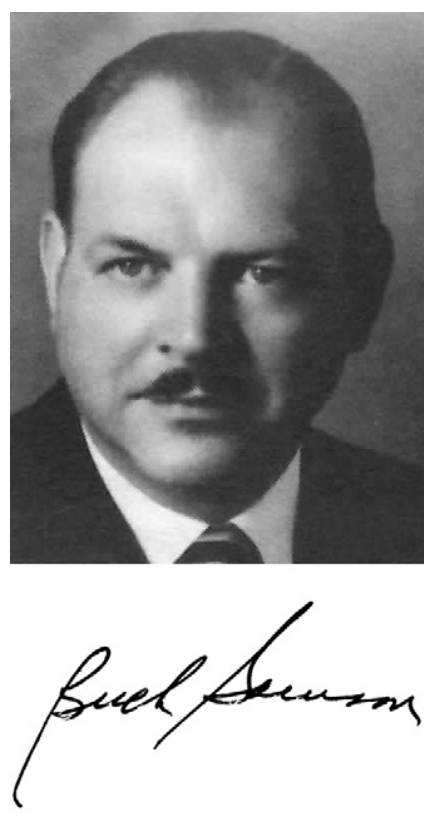

FIGURE 1. Paul "Buck" Samson. Courtesy of Pacific Coast Surgical Association.

performing what was probably the first successful pneumonectomy in the overseas theater using the individual ligation technique. $^{1}$

Importantly, thoracic surgery arose in part as an offshoot of experiences from World War II. During the Civil War, penetrating chest injuries were sealed early to avoid an open pneumothorax; however, such technique resulted in infections and a mortality rate of $63 \% .{ }^{4}$ Aseptic surgery and abdominal surgery were better developed by World War I, but the discipline of thoracic surgery remained in its infancy, and the mortality rate associated with treatment of chest wounds remained nearly $25 \% .^{4}$ Notwithstanding progress in thoracic surgery between World War I and World War II, physiologic principles including restoring cardiac and pulmonary function had not been widely appreciated and evaluated. Samson, along with Brewer and Thomas H. Burford, 51st AATS president, persuaded the surgeons at headquarters to set up a thoracic surgery center on a trial basis. ${ }^{3,4}$ In July 1943, the first such chest center in the Army Medical Corps was established in Bizerte, Tunisia. To overcome the official skepticism of the leadership, Samson, Brewer, and Burford demonstrated that well-trained thoracic surgeons could substantively lower the mortality rates of chest wounds. They proposed 3 advances in the base section 
management of chest wounds: (1) treatment of organizing hemothorax and hemothoracic empyema, with the refinement of pulmonary decortication for trapped lung; (2) surgical management of intrathoracic metallic foreign bodies; and (3) introduction of penicillin for treating pleural, pulmonary, and bloodstream infections. ${ }^{4}$ Additionally, they recognized the proper indications for thoracotomy and introduced a new syndrome, "the wet lung in war casualties," now known as respiratory distress syndrome. ${ }^{4}$ Samson ${ }^{5}$ stated:

The development of an integrated system of "thoracic" resuscitation in forward hospitals has paid excellent dividends in lives saved and morbidity reduced. We would be remiss if much of the information thus gained was not applied to the solution of similar problems in civilian practice. Early contact with many wounded soldiers has served to emphasize the fact that clinical shock is perpetuated by disturbances of cardiorespiratory equilibrium. Continued experience has strengthened the concept that patients with severe thoracic wounds should be resuscitated thoroughly, that time itself plays an important role and that, with few exceptions, nothing is gained and often much is lost by hurriedly submitting the thoracic casualty to the surgeon's knife.*

After the conclusion of World War II, Samson retired from active service as a lieutenant colonel in January 1946. He received numerous commendations for his military service, including the Bronze Arrowhead for D-Day landing in southern France in 1944, the Legion of Merit (Mediterranean theater of operations, 1945), Bronze Service Stars for 7 campaigns, and 3 service medals.

Samson returned to northern California to continue his thoracic surgery practice, specializing in the treatment of tuberculosis and empyema. When he and David J. Dugan, 56th AATS president, became partners in the practice in 1946, Samson was one of the first surgeons in the West to limit his scope of practice to thoracic surgery and was considered the 22nd "pure" thoracic surgeon in the country. ${ }^{6}$ That same year and until 1958, Samson started and directed the thoracic surgery training program at Highland General Hospital in Oakland, which was the first approved training service in thoracic surgery north of Los Angeles on the West Coast. Samson's surgical expertise was widely recognized, and he assisted Emile Holman, 33rd AATS president, at Stanford Medical School in San Francisco in performing Holman's first 2 major thoracic operations. He helped train Stanford residents and had an appointment at Stanford University, eventually retiring as clinical professor of surgery.

\footnotetext{
* From Samson PC, Burbank B, Brewer LA, Burford TH. Immediate care of the wounded thorax. JAMA. 1945;129:606-10. Published with permission of the American Medical Association.
}

Samson recognized the need to document the surgical lessons that he and his colleagues gained from the war, and, later in practice, he emphasized to his trainees the importance of clinical and experimental research in thoracic surgery. He authored over 130 scientific contributions ranging from complications of tuberculosis and other chest infections, pulmonary and mediastinal tumors, esophageal disorders, and aortic coarctation, including over 20 publications on thoracic trauma during the war and in civilian life. His medical experience in the military provided the basis for his contributions to the management of thoracic trauma, which he recorded in 2 books. He also reported the military experience with battle wounds and injuries of the heart and pericardium, reviewing 75 cases of such injuries. $^{7}$

Just before entering active military service in World War II, Samson married Marion Smith, who remained his champion and constant companion. ${ }^{6}$ He had achieved notoriety as an Olympic swimmer on the same 1928 Olympic team as the famed Johnny Weissmuller, who later went on to a successful acting career as Tarzan. During World War II, Samson's joie de vivre was evident, as Dugan ${ }^{6}$ recalled: "In those days, Samson's close friend Trader Vic had a single restaurant in Oakland. Unbeknownst to Vic, Samson and his Army buddies started the first branch in the Italian theater, somewhat on the order of the bar in the popular M.A.S.H. television program." Samson was a gentle, considerate individual with a keen sense of humor, who attracted both affection and respect. His death at age 76 on February 10, 1982, ended one of the most influential careers in American thoracic surgery. ${ }^{1,3}$

After World War II, Samson was one of the pioneers who helped solidify the concept of thoracic surgery as a specialty. Samson was a founding member of the American Board of Thoracic Surgery in 1948 and served on its examining board for 7 years. ${ }^{8,9}$ Samson's leadership abilities were widely recognized, and he achieved numerous honors during his illustrious career, including being secretary of the AATS from 1951 to 1956 and its president from 1967 to 1968. ${ }^{1,2,10} \mathrm{He}$ was a founder and the first president of The Society of Thoracic Surgeons and a recipient of its Distinguished Service Award. He served as chairman of the Board of Governors of the American College of Surgeons from 1960 to 1963 and a member of the Board of Regents from 1963 to 1972 . He served as president of the Pacific Coast Surgical Association, president of the American Thoracic Society, and president of the Tuberculosis and Health Association of California.

In his presidential address at the 48th Annual Meeting of the AATS in 1968, Samson ${ }^{11}$ discussed the training and practice of thoracic surgery as the Association entered the second half century of its existence. Looking back to1937, the committee chaired by Dr Eggers "reported in effect that there was no need then for specialty certification 
in thoracic surgery." 11 Three decades later, however, Samson ${ }^{11}$ noted:

The war years changed this sentiment considerably. It became obvious early in the conflict that soldiers with thoracic wounds fared better when treated by those with special experience. The end of the war saw many surgeons returning for further thoracic surgical training. A short time later, the report to the second Eggers Committee led to the formation of the Board of Thoracic Surgery in 1948.

Furthermore, Samson ${ }^{11}$ described his vision of the compleat thoracic surgeon:

I think he is and will be a surgeon of many facets and many skills and each may not have these in equal abundance. His training both in basic and in thoracocardiovascular surgery has been broad and varied. He is at once a product of his training, his practice environment (university, institution, or private), his wishes, and his opportunities. He may do general thoracic surgery only or cardiovascular surgery exclusively. He is characterized by being able to think "thoracic" and think "cardiac." Operatively, he is at home in the chest as well as for those occasional forays into the neck, or into the abdomen, which are at times necessary to care for problems that are primarily thoracic-based.

In 1974, Samson's close friends and colleagues founded the Samson Thoracic Surgical Society of Western North America because they believed that such an honor was due him during his lifetime. ${ }^{1,6}$ Considered the most lasting tribute to Samson's leadership, this organization has become a prominent regional surgical association. ${ }^{2}$ From the beginning, because of Samson's friendship with Brian Blades (the 37th president of the AATS), the Editor of the Journal of Thoracic and Cardiovascular Surgery, arrangements were made to publish papers presented at this meeting in the Journal. ${ }^{12}$ In 1983, the Samson Thoracic Surgical Society was renamed The Western Thoracic Surgical Association to achieve representation at the American College of Surgeons Board of Governors, which did not recognize societies named after an individual. ${ }^{12}$ Samson's name, however, is preserved in the Samson Endowment Fund, the Samson prize for the best resident paper, and other activities of The Western Thoracic Surgical Association.

Arthur Thomas, his long-time friend and past president of The Western Thoracic Surgical Association, saluted Samson, "Here's to our Godfather and to his Angel-in-charge of his Society." An accomplished clinician and educator, Samson took great pride in establishing a thoracic surgery training program and in his contributions to this surgical discipline, the development of which spanned his professional career. ${ }^{10}$

\section{References}

1. Jones KE. Twenty-five years of excellence: the legacy and the challenge. $J$ Thorac Cardiovasc Surg. 2000;119:203-9.

2. Roe BB. Paul C. Samson, M.D., 1905-1982. Ann Thorac Surg. 1982;34:479.

3. Brewer LA III. In memoriam: Paul C. Samson. Am J Surg. 1982;144:165.

4. Brewer LA III. The contributions of the Second Auxiliary Surgical Group to military surgery during World War II with special reference to thoracic surgery. Ann Surg. 1983;197:318-26.

5. Samson PC, Burbank B, Brewer LA, Burford TH. Immediate care of the wounded thorax. JAMA. 1945;129:606-10.

6. Dugan DJ. Paul C. Samson, M.D., 1905-1982. Part II. Personal recollections. Ann Thorac Surg. 1983;36:502-4

7. Samson PC. Battle wounds and injuries of the heart and pericardium: experiences in forward hospitals. Ann Surg. 1948;127:1127-49.

8. Ellison RG. Significant events in the history of The Society of Thoracic Surgeons. Ann Thorac Surg. 1972;14:577-604.

9. Ellison RG. The Society of Thoracic Surgeons: the first twenty years. Ann Thorac Surg. 1984;37:1-8.

10. Ellison RG. Paul C. Samson, M.D., 1905-1982. Part I. His contributions to The Society of Thoracic Surgeons. Ann Thorac Surg. 1983;36:500-1.

11. Samson PC. The compleat thoracic surgeon. J Thorac Cardiovasc Surg. 1968;56: 155-62.

12. Pomerantz M. Brief history of The Western Thoracic Surgical Association. Available at: http://www.westernthoracic.org/about_history.html. 